\title{
EVALUASI PERENCANAAN DAN PENGADAAN ASET PADA BPKBMD KABUPATEN MINAHASA UTARA
}

\author{
Ferina M A. Saraun 1 \\ Lidia Mawikere 2 \\ 1,2, Fakultas Ekonomi dan Bisnis Jurusan Akuntansi \\ Universitas Sam Ratulangi Manado \\ email: 1 ferinamariasaraun@gmail.com \\ 2lidiamawikere76@yahoo.com
}

\begin{abstract}
Asset is one of the elements that must be managed properly in order to produce reliable information in the financial statements regions. Martinet sectoral asset management (asset) carries a significant effect on the perfection of balance sheet presentation area. The aim of this study is to see and know the planning and procurement of assets in Financial Management Board and the Regional Property North Minahasa Regency regulatory interior minister 17 in 2007 seen from the cycle of sectoral asset management are applied as well as the completeness of the source document. The method used is qualitative method with descriptive analysis techniques. The results showed that BPKBMD North Minahasa Regency is appropriate. However, BPKBMD North Minahasa regency should coordinate better with all SKPD as users / persons responsible for the preparation of the planning and procurement of assets in order to realize the principles of Good Governance.
\end{abstract}

Keywords: Planning, Procurement

\section{Latar Belakang}

\section{PENDAHULUAN}

Mengacu pada prinsip Good Govermence bahwa pemerintah, baik itu pemerintah pusat maupun pemerintah daerah harus menyajikan laporan keuangan yang transparan dan akuntabel. Transparan atau Transparasi sendiri yaitu memberikan informasi keuangan yang terbuka dan jujur kepada masyarakat berdasarkan pertimbangan bahwa masyarakat memiliki hak untuk mengetahui secara terbuka dan menyeluruh atas pertanggung jawaban pemerintah daerah dalam pengelolaan sumber daya yang dipercayakan kepadanya. Sedangkan Akuntabel atau Akuntabilitas sendiri yaitu mempertanggungjawabkan pengelolaan sumber daya serta pelaksanaan kebijakan yang dipercayakan kepada pemerintah daerah dalam mencapai tujuan yang telah ditetapkan secara periodik. Tujuannya agar semua yang dilaporkan bias dipertanggung jawabkan kepada masyarakat, termasuk aset berupa barang milik Negara maupun barang milik daerah. Secara umum barang merupakan bagian dari kekayaan yang adalah satuan tertentu yang dapat dinilai, dihitung, diukur, tidak termasuk juga uang dan surat berharga.

Aset merupakan salah satu unsur yang harus dikelola dengan baik agar menghasilkan informasi yang andal dalam laporan keuangan daerah. Pengelolaan aset daerah merupakan sesuatu yang harus dilaksanakan dengan baik agar dapat memberikan gambaran tentang kekayaan daerah, adanya kejelasan status kepemilikan, pengamanan barang daerah, peningkatan Pendapatan Asli Daerah (PAD) dengan pemanfaatan aset daerah yang ada serta dapat digunakan untuk dasar penyusunan laporan keuangan. Pengelolaan barang milik daerah harus dilakukan secara efektif, efisien, dan ekonimis sehingga pengamanan aset daerah dapat terjaga dengan baik 
Proses perencanaan dilaksanakan dengan prosedur yang berjenjang sesuai mekanisme perencanaan yang didasarkan pada Undang-Undang Nomor 25 Tahun 2005 tentang sistem Perencanaan Nasional dan Peraturan Pelaksanaannya yang dimulai dari usulan Kepala SKPD kepada tim anggaran eksekutif untuk dimasukan ke dalam RAPBD. Usulan tersebut dilakukan dengan berbagai tahapan, seperti adanya proses musrenbang (musyawarah perencanaan pembangunan) dan kajian-kajian yang menyatakan diperlukan aset/ barang milik daerah tersebut. Selanjutnya, RAPBD disampaikan kepada DPRD untuk mendapatkan legalisasi menjadi APBD dengan dilengkapi berbagai dokumen seperti Dokumen Pelaksana Anggaran (DPA). Kemudian, dilaksanakan Pengadaan berdasarkan kewenangan masingmasing Instansi dengan prosedur berdasarkan Peraturan Presiden Nomor 54 tahun 2009 sebagaimana telah diubah dengan Peraturan Presiden Nomor 35 Tahun 2011. Setiap tahun pemerintah daerah menyusun Anggaran Pendapatan dan Belanja Daerah sesuai prosedur dan mekanisme yang berlaku. Pemerintah Kabupaten Minahasa Utara sendiri pada tahun 2015 telah melakukan perencanaan dan pengadaan aset pada seluruh Satuan Kerja Perangkat Daerah (SKPD), Satuan Kerja Perangkat Kerja Daerah (SKPKD), dan semua kantor yang ada di wilayah Kabupaten Minahasa Utara sesuai dengan Peraturan Menteri Dalam Negeri Nomor 52 Tahun 2015 tentang Pedoman Penyusunan Anggaran Pendapatan dan Belanja Daerah (APBD).

Untuk mengetahui bagaimana Perencanaan dan Pengadaan Aset/Barang milik daerah Kabupaten Minahasa Utara telah terselenggara dengan baik sesuai dengan Peraturan Pemerintah Dalam Negeri Nomor 17 Tahun 2007.Maka penelitian ini mencoba memahami lebih tentang Perencanaan dan Pengadaan Aset/Barang milik daerahpada Badan Pengelolaan Keuangan dan Barang Milik Daerah Kabupaten Minahasa Utara.

\section{Tujuan Penelitian}

1. Untuk mengetahui apakah perencanaan dan pengadaan Aset/Barangmilik daerah telah terselenggara dengan baik berdasarkan Peraturan Pemerintah Dalam Negeri Nomor 17 tahun 2007 pada Pemerintah Kabupaten Minahasa Utara.

2. Untuk mengetahui bagaimanakah proses perencanaan dan pengadaan aset/barang milik daerah pada Pemerintah Kabupaten Minahasa Utara.

\section{Pengertian Aset}

\section{TINJAUAN PUSTAKA}

Aset menurut Standart Akuntansi Pemerintahan merupakan sumber daya ekonomi yang dikuasai dan/atau dimiliki oleh pemerintah sebagai akibat dari masa lalu dan dari mana manfaat ekonomi dan/atau social di masa depan. Yang diharapkan dapat diperoleh baik oleh pemerintah maupun masyarakat, serta dapat diukur dalam satuan uang, termasuk sumber daya nonkeuangan yang diperlukan untuk penyediaan jasa bagi masyarakat umum dan sumber-sumber daya yang dipelihara karena alasan sejarah dan budaya.

\section{Pengertian Barang Milik Daerah}

Barang Milik Daerah menurut Pemendagri No. 17 Tahun 2007, adalah semua barang yang dibeli atau diperoleh atas beban Anggaran Pendapatan dan Belanja Daerah atau perolehan lainnya yang sah antara lain:

1. Barang yang diperoleh dari hibah/sumbangan atau yang sejenis;

2. Barang yang diperoleh sebagai pelaksanaan dari perjanjian/kontrak;

3. Barang yang diperoleh berdasarkan ketentuan undang-undang; atau

4. Barang yang diperoleh berdasarkan putusan pengadilan yang telah memperoleh kekuatan hukum tetap.

Barang milik daerah sebagaimana tersebut diatas, terdiri dari: 
a. Barang yang dimiliki oleh Pemerintah Daerah yang penggunaanya/ pemakaiannya berada pada Satuan Kerja Perangkat Daerah (SKPD/Instansi/Lembaga Pemerintah Daerah Lainnya sesuai ketentuan peraturan perundang-undangan);

b. Barang yang dimiliki oleh Pemerintah Daerah atau Badan Usaha Milik Daerah lainnya yang status barangnya dipisahkan.

\section{Perencanaan Dan Pengadaan Aset}

Dalam M Yusuf (2010 : 41) Perencanaan merupakan tahapan paling penting dari salah satu tahap penyusunan Aset. Pelaksanaan Perencanaan kebutuhan dan penganggaran perlu terkoordinasi dengan baik dengan memperhatikan standarisasi yang telah ditetapkan sesuai kondisi daerah masing-masing. Mengenai perencanaan kebutuhan dan penganggaran bukanlah merupakan suatu kegiatan yang berdiri sendiri, tetapi merupakan kegiatan yang tidak terpisahkan dalam pengelolaan barang milik daerah. Dalam perencanaan kebutuhan dan penganggaran barang daerah perlu adanya pemahaman dari seluruh satuan kerja perangkat daerah terhadap tahapan kegiatan pengelolaan barang milik daerah sehingga koordinasi dan sinkronisasi dalam kegiatan tersebut dapat dilakukan dengan baik.

Perencanaan dan penganggaran kebutuhan dilakukan dengan melihat standart kebutuhan meliputi, standart jenis, macam, jumlah, dan besarnya barang milik daerah yang dibutuhkan, juga merupakan standarisasi sarana dan prasarana kerja Pemerintah Daerah. Proses perencanaan dan penganggaran tidak terlepas dari kegiatan dalam pemenuhan barang yang disesuaikan standarisasi satuan harga barang. Satuan harga barang disusun berdasarkan hasil survey yang dilaksanakan oleh SKPD beserta instansi yang terkait. Jumlah dan kualitas barang harus disesuaikan dengan standarisasi barang yang berlaku yang tercantum dalam peraturan Kepala Daerah. (Nyemas Hasfi, et al. 2013)

Pemerintah Daerah merupakan organisasi yang sangat dinamis dalam menjalankan roda pemerintahannya termasuk Merencanakan Kebutuhan Aset. Pelayanan peningkatan kesehjateraan masyarakat memiliki banyak sekali indicator sehingga pemerintah melalui Peraturan Pemerintah Nomor 41 tahun 2007 memberikan kewenangan-kewenangan meliputi:

1. Bidang Pendidikan,Pemuda dan Olahraga;

2. Bidang Kesehatan;

3. Bidang Sosial,Tenaga Kerja dan Transmigrasi;

4. Bidang Perhubungan,Komunikasi, dan Informatika;

5. Bidang Kependudukan, dan Catatan Sipil;

6. Bidang Kebudayaaan, dan Pariwisata

Salah satu sistem perencanaan untuk pembelian aset/barang milik daerah yaitu, perencanaan akan Pengadaan Kebutuhan aset/ barang milik daerah yang dilakukan oleh SKPD. Hal ini karena SKPD mengetahui jumlah kebutuhan tanah, jumlah kebutuhan peralatan dan mesin, jumlah kebutuhan bangunan dan gedung, jumlah kebutuhan jalan, irigasi, instalasi, dan jaringan, jumlah kebutuhan aset/barang milik daerah lainnya, seperti buku perpustakaan, hewan, tumbuh-tumbuhan, serta jumlah kebutuhan aset/barang milik daerah yang tidak berwujud.

Untuk mencukupi kebutuhan sarana dan prasarana, diperlukan suatu perencanaan yang baik agar prasarana yang dibeli tidak menjadi barang rongsokan atau tidak dapat dimanfaatkan. Pada kenyataannya, pada masa- masa yang lalu, seringkali sarana dan prasarana diadakan berdasarkan keinginan subjektif. Sarana dan prasarana merupakan bentuk alat yang dapat dimanfaatkan dan digunakan dalam rangka mendukung kegiatan pemerintah.

Pencatatan Perencanaan dan Pengadaan Kebutuhan Aset Daerah mekanismenya telah diatur dalam Peraturan Pemerintah Dalam Negeri Nomor 17 Tahun 2007 tentang pedoman teknis pengelolaan Barang Milik Daerah Sebagaimana telah dijelaskan. Oleh karena itu, kreativitas daerah untuk dapat menciptakan mekanisme pengumpulan data dari SKPD sangat 
diperlukan.Misalnya Aset harus dapat dihitung dengan tepat, begitu juga dengan jumlah kondisi aset/barang yang tersedia harus jelas.

Menurut Peraturan Pemerintah Dalam Negeri No 13 tahun 2006, setiap pemerintah daerah mengajukan RAPBD kepada DPRD wajib melampirkan jumlah aset/barang tidak baik maka akan sulit memenuhi lampiran RAPBD tersebut. Dalam sistem perencanaan anggaran daerah, salah satu permasalahan yang sering muncul dari Tim Anggaran Eksekitif maupun Tim Anggaran Legislatif adalah permintaan data jumlah aset/barng yang sudah ada yang sedang dibeli pada tahun anggaran berjalan, terdapat tiap-tiap SKPD sebagai pembanding untuk memutuskan usulan alokasi pembelanjaan terhadap suatu aset/barang.

Sesuai dengan Permendagri No. 17 Tahun 2007 Pengadaan merupakan hasil dari daftar rencana yang akan direalisasi berupa barang/jasa. Dalam hal Pengadaan Aset/Barang milik daerah adalah Pengadaan barang daerah dilaksanakan oleh panitia/pejabat pengadaan dengan tujuan:

1. Tertib administrasi pengadaan barang daerah;

2. Tertib administrasi pengelolaan barang daerah;

3. Pendayagunaan barang daerah secara maksimal sesuai dengan tujuanpengadaan barang daerah; dan,

4. Tercapainya tertib pelaksanaan penatausahaan barang daerah.

Administrasi pengadaan barang daerah yang dilaksanakan oleh panitia/pejabat pengadaan mencakup seluruh kegiatan pengadaan barang daerah sesuai ketentuan peraturan perundang-undangan. Yang dimaksud dengan pengadaan disini yaitu pengadaan atas beban APBD, dalam hubungan ini setiap kepala SKPD bertanggung jawab untuk melaksanakan pengadaan barang milik daerah dalam lingkungan wewenangnya dan bertanggung jawab pula untuk melaporkan/ menyampaikan daftar hasil pengadaan barang milik daerah kepada Kepala Daerah melalui pengengelola.

\section{Jenis Penelitian}

\section{METODE PENELITIAN}

Dalam penelitian ini menggunakan data kualitatif yaitu mengenai Profil, Badan Pengelolaan Keuangan dan Aset Milik Daerah,Satuan Kerja Perangkat Daerah (SKPD), Struktur Organisasi, dan Informasi tentang Perencanaan dan Pengadaan Aset Daerah telah terselenggara dengan baik.

\section{Tempat dan Waktu Penelitian}

Penelitian ini dilakukan pada Badan Pengelolaan Dan Barang Milik Daerah Kabupaten Minahasa Utara. yang beralamat di Jalan SBY Airmadidi Minahasa Utara. Penelitian ini dilakukan dalam jangka waktu dua bulan, yaitu bulan September dan Oktober 2015.

\section{Objek Penelitian}

Objek penelitian ini yaitu pada Badan Pengelolaan Keuangan dan Barang Milik Daerah Kabupaten Minahasa Utara sesuai dengan judul skripsi yg dimaksud.

\section{Metode Pengumpulan Data}

Metode pengumpulan data adalah metode yang digunakan untuk mendapatkan data, dalam suatu metode penelitian. Teknik Pengumpulan data yang dilakukan yaitu Teknik Wawancara dan Teknik Dokumentasi.

\section{Metode Analisis}

Metode penelitian yang digunakan dalam penelitian ini adalah metode penelitian kualitatif yaitu metode penelitian yang berlandaskan pada filsafat postpotivisme, digunakan untuk meneliti pada kondisi-kondisi objek yang alamiah, (sebagai lawannya dalam 
eksperimen) dimana peneliti adalah instrumen kunci, pengambilan sampel sumber data dilakukan secara purposive dan snowball, teknik pengumpulan dengan trianggulasi (gabungan), analisis data yang bersifat induktif/kualitatif, dan hasil penelitian kualitatif lebih menekankan makna generalisasi.

\section{HASIL PENELITIAN DAN PEMBAHASAN}

\section{Hasil Penelitian}

\section{Hasil Perencanaan Aset di Kabupaten Minahasa Utara}

Menurut hasil wawancara dengan kepala Badan Pengelolaan Keuangan dan Barang Milik Daerah Kabupaten Minahasa Utara Perencanaan Aset Kabupaten Minahasa utara sudah terlaksana dengan baik. Salah satunya pada Dinas Kesehatan Kabupaten Minahasa Utara yang merupakan salah satu dinas yang membutuhkan biaya yang sangat besar tiap tahunnya. Proses perencanaan kebutuhan barang milik daerah terakhir sudah dilakukan pada tahun 2013. BPKBMD sebagai pembantu pengelola telah menerapkan Perencanaan aset sesuai dengan prosedur yang seharusnya dilakukan yaitu sesuai dengan Permendagri Nomor 17 Tahun 2007, yaitu:

1) Satuan Kerja Perangkat Daerah (SKPD) sebagai pengguna barang merencanakan dan menyusun kebutuhan barang dalam Rencana Kerja dan Anggaran Satuan Kerja Perangkat Daerah ( RKA-SKPD) sebagai bahan dalam penyunsunan Rencana Anggaran Pendapatan dan Belanja Daerah (RAPBD).

2) Masing- masing SKPD menyusun Rencana Kebutuhan Barang dan Rencana Kebutuhan Pemeliharaan Barang kemudian menyampikan kepada Pengelola melalui pembantu pengelola untuk meneliti dan menyusun menjadi Rencana Daftar Kebutuhan Barang Milik Daerah (RDKBMD) dan Rencana Kebutuhan Pemeliharaan Barang Milik Daerah (RKPBMD).

3) Rencana Kebutuhan Barang SKPD disusun berdasarkan standarisasi sarana dan prasarana kerja pemerintah daerah yang ditetapkan kepala daerah.

4) Setelah APBD, ditetapkan setiap SKPD menyusun Daftar Rencana Tahunan Barang dan disampaikan kepada Kepala Daerah melalui pengelola.

5) Berdasarkan Rencana Tahunan Barang dari semua SKPD, diteliti dan dihimpun menjadi Daftar Kebutuhan Barang Milik Daerah (RKBMD) untuk satu tahun anggaran.

6) Daftar kebutuhan barang daerah tersebut dijadikan pedoman dalam pelaksanaan pengadaan dan pemeliharaan barang milik daerah dan;

7) Format Rencana Kebutuhan Barang SKPD (RKB SKPD) (Lampiran 1) dan Rencana Kebutuhan Pemeliharaan Barang SKPD (Lampiran 2).

Perencanaan Barang pada Dinas Kesehatan Kabupaten Minahasa Utara Tahun 2013 berjumlah 47 jenis barang dan 717 buah barang. Diantaranya peralatan kantor, bangunan klinik puskesmas laboratorium, peralatan elektronik, peralatan dapur dan peralatan lainnya yang menjadi kebutuhan Dinas Kesehatan dalam menjalankan tugasnya. Jumlah Harga Satuan dari kebutuhan barang Dinas Kesehatan yaitu Rp 7.009.007.962 dan Jumlah Harga pembelian yaitu Rp 1.465.088.626.

\section{Hasil Pengadaan Aset di Kabupaten Minahasa Utara}

Pengadaan barang Dinas Kesehatan Kabupaten Minahasa Utara dilakukan pada satu tahun sesudah melakukan perencanaan yaitu pada tahun 2014. Proses pengadaan juga sudah terealisasi sesuai dengan baik. Dinas kesehatan sesuai dengan Permendagri Nomor 17 tahun 2007 yaitu

1) Panitia Pengadaan ditetapkan dengan Keputusan Kepala Daerah dengan susunan keanggotaannya melibatkan unsur teknis terkait;

2) Panitia Pengadaan menyelenggarakan tender/lelang dan mengambil keputusan dalam suatu rapat yang dituangkan dalam Berita Acara Lelang mengenai calon pemenang 
atas dasar harga terendah dikaitkan dengan harga perkiraan sendiri (owner estimate) yang dapat dipertanggung jawabkan untuk kualitas barang yang dibutuhkan, selanjutnya menyampaikan Berita Acara tersebut disertai saran kepada Kepala Daerah dan/atau Sekretaris Daerah untuk menetapkan Pemenang Lelang.

Dalam Berita Acara Lelang dimaksud memuat antara lain:

1) hari, tanggal dan tempat pelaksanaan lelang;

2) anggota panitia yang hadir;

3) rekanan yang diundang, rekanan yang hadir, rekanan yang memenuhi syarat; dan

4) surat-surat penawaran yang masuk.

3) Setelah ditetapkan calon pemenang lelang, Kepala Daerah atau pengelola atau pengguna, menetapkan pemenang lelang;

4) Pelaksanaan mengadakan/pekerjaan dilakukan dengan cara sebagai berikut:

1) membuat Surat Perjanjian yang ditandatangani oleh Kepala Daerah atau pengelola atau Kepala SKPD;dan

2) sepanjang pengadaan/pekerjaan tidak dilakukan melalui lelang, maka pelaksanaan pengadaan/pekerjaan dilakukan dengan Surat Perintah Kerja yang ditandatangani oleh Kepala SKDP dan/atau pejabat pengadaan.

Dalam Surat Perintah Pengadaan/Pekerjaa tersebut diatas,merupakan dasar untuk penerimaan barang harus dengan tegas membuat dan menyatakan jumlah barang dan biaya maupun syarat-syarat lain yang diperlukan.

5. Penerimaaan barang dilaksanakan oleh penyimpan barang dan/atau pengurus barang setelah diperiksa oleh Panitia Pemeriksa Barang Daerah dengan membuat berita acara pemeriksaan.

6. Pembayaran hanya dapat dilakukan apabila melampiri dokumen-dokumen sesuai dengan ketentuan yang berlaku.

Pada Dinas Kesehatan Kabupaten Minahasa Utara yang merupakan salah satu SKPD dengan biaya kebutuhan pertahun yang sangat tinggi telah melakukan perencanaan dan penganggaran pada tahun terakhir yaitu 2013.Rencana Kebutuhan Barang pada Dinas Kesehatan pada tahun 2013 telah terselenggara berupa peralatan kantor, bangunan gedung kantor, bangunan klinik puskesmas laboratorium, tugu, alat dapur, alat-alat kedokteran dan lain lain yang sudah tercantum dalam Daftar Rencana Kebutuhan Barang Unit (DRKBU). Sesuai dengan data diatas dapat disimpulkan bahwa perencanaan barang pada Dinas Kesehatan berjumlah (47) barang.

\section{Analisis Perencanaan Aset di Kabupaten Minahasa Utara}

Pada dasarnya mekanisme pencatatan rencana kebutuhan barang secara umum telah diatur dalam Peraturan Pemerintah Dalam Negeri Nomor 17 Tahun 2007. Dalam hal perencanaan, tidak dilakukan untuk lima tahun tetapi pertahun dengan pertimbangan kebutuhan serta jumlah pegawai yang berubah tiap tahunnya. Oleh karena itu, kreatifitas daerah untuk dapat menciptakakan mekanisme pengumpulan data dari SKPD sangat diperlukan. Perencanaan Aset yang dikelola oleh Pemerintah Daerah telah diatur oleh Pemerintah Pusat dalam berbagai peraturan yang paling umum digunakan diantaranya PP No.6 Tahun 2006 tentang Pengelolaan Barang Milik Negara/Daerah disertai pedoman teknisnya dalam Permendagri No 17 Tahun 2014 dan direvisi terbaru dari PP No.6 Tahun 2006 yaitu PP No.27 Tahun 2014 tentang Pengelolaan Barang Milik Negara/Daerah.Peraturan Pemerintah Nomor 27 Tahun 2014. Dalam pasal 10 ayat (1), (2), dan (3) pada peraturan tersebut dijelaskan bahwa Alur proses perencanaan dan penganggaran BMD yaitu :

1. Pengguna barang menghimpun usul rencana kebutuhan barang yang diajukan oleh kuasa pengguna barang yang berada di lingkungan kantor yang dipimpinnya. 
2. Pengguna barang menyampaikan usul rencana kebutuhan Barang Milik Daerah kepada pengelola barang.

3. Pengelola barang melakukan penelaan atas usul rencana kebutuhan Barang Milik Daerah tersebut bersama pengguna barang dengan memperhatikan data barang pada pengguna barang dan/atau pengelola barang dan menetapkannya sebagai rencana kebutuhan barang milik Negara/daerah.

Satuan Kerja Perangkat Daerah sebagai pengguna barang merencanakan dan menyusun kebutuhan barang dalam Rencana Kerja dan Anggaran Satuan Kerja Perangkat Daerah (RKA-SKPD) sebagai bahan dalam penyusunan Rencana Anggaran Pendapatan dan Belanja Daerah (RAPBD), kemudian masing-masing SKPD menyusun Rencana Kebutuhan Barang dan Rencana Kebutuhan Pemeliharaan Barang dalam bentuk usulan kemudian menyampaikan kepada pengelola melalui pembantu pengelola. Pembantu Pengelola menghimpun usulan RKBMD dan RKPBMD untuk diteliti namun tidak disusun menjadi dokumen Rencana Daftar Kebutuhan Barang Milik Daerah (RDKBMD) dan Rencana Kebutuhan Pemeliharaan Barang Milik Daerah (RKPBMD). Dari usulan RKBMD, ketika dihasilkan Dokumen Pelaksanaan Anggaran (DPA), langsung menjadi Daftar Kebutuhan Barang (DKB) dan tidak di proses lagi menjadi dokumen DKBMD ataupun DKPBMD.

Berdasarkan hasil penelitian, dapat dilihat bahwa BPKBMD sebagai pembantu pengelola telah menerapkan Perencanaan aset sesuai dengan prosedur yang seharusnya dilakukan. Dokumen sumber Perencanaan dan Pengadaan Aset berdasarkan Permendagri No 17 Tahun 2007 adalah sebagai berikut :

1) RKBMD sebagai dasar penyusunan Rencana Kerja dan Anggaran (RKA) masingmasing satuan kerja perangkat daerah juga sebagai bahan penyusunan Rencana APBD

2) RKPBMD sebagai dasar penyusunan Rencana Kerja dan Anggaran (RKA) masingmasing satuan kerja perangkat daerah juga sebagai bahan penyusunan Rencana APBD.

Pada Dinas Kesehatan Kabupaten Minahasa Utara yang merupakan salah satu SKPD dengan biaya kebutuhan pertahun yang sangat tinggi telah melakukan perencanaan dan penganggaran pada tahun terakhir yaitu 2013.Rencana Kebutuhan Barang pada Dinas Kesehatan pada tahun 2013 telah terselenggara berupa peralatan kantor, bangunan gedung kantor, bangunan klinik puskesmas laboratorium, tugu, alat dapur, alat-alat kedokteran dan lain lain yang sudah tercantum dalam Daftar Rencana Kebutuhan Barang Unit (DRKBU). Sesuai dengan data diatas dapat disimpulkan bahwa perencanaan barang pada Dinas Kesehatan berjumlah (47) barang. Setelah melakukan perencanaan aset/barang Dinas Kesehatan melakukan Realisasi atau pengadaanya pada tahun berikut yaitu tahun 2014 .

\section{Analisis Pengadaan Aset di Kabupaten Minahasa Utara}

Menurut Peraturan Presiden Republik Indonesia Nomor 54 Tahun 2010 bahwa Pengadaan Barang/Jasa Pemerintah yang efisien, terbuka dan kompetitif sangat diperlukan bagi ketersediaan Barang/Jasa yang terjangkau dan berkualitas, sehingga akan berdampak pada peningkatan pelayanan publik. Seperti dalam aturan Kepala Satuan Kerja Perangkat Daerah menetapkan Panitia Pengadaan pada masing-masing SKPD yang ditetapkan dengan keputusan kepala daerah. Setelah itu panitia pengadaan menyelenggarakan tender/lelang dan mengambil keputusan dalam rapat dan dituangkan dalam Berita Acara Lelang mengenai calon pemenang atas dasar harga terendah dikaitkan dengan harga perkiraan sendiri (owner estimate) yang dapat dipertanggungjawabkan untuk kualitas barang yang dibutuhkan, selanjutnya menyampaikan berita acara tersebut disertai saran kepada Kepala Daerah dan/atau Sekretaris Daerah untuk menetapkan Pemenang Lelang. Pelaksanaan Pengadaan dilakukan dengan cara sebagai berikut: 
8) Membuat Surat Perjanjian yang ditandatangani oleh Kepala Daerah atau pengelolah atau Kepala SKPD; dan

9) Sepanjang Pengadaan/Pekerjaan dilakukan dengan Surat Perintah Kerja yang ditandatangani oleh Kepala SKPD dan/atau pejabat pengadaan.

Dalam surat perintah pengadaan/pekerjaan diatas, merupakan dasar untuk penerimaan barang, harus dengan tegas memuat dan menyatakan jumlah barang dan biaya maupun syarat-syarat yang diperlukan. Setalah itu Penerimaan barang dilaksanakan oleh penyimpan barang dan/atau pengurus barang selaku SKPD masing-masing setelah diperiksa oleh Panitia Pemeriksa Barang Daerah dengan membuat Berita Acara Pemeriksaan. Dan yang terakhir Pembayaran hanya dapat dilakukan apabila melampiri dokumen-dokumen sesuai dengan ketentuan yang berlaku.pengadaan yang sudah dilakukan oleh Dinas Kesehatan Kabupaten Minahasa Utara sesuai dengan daftar rencana kebutuhan barang yang sudah tersusun. Akan tetapi pada saat melakukan pengadaan, didapati adanya penambahan nilai barang yang tidak terduga untuk Rehabilitasi Bangunan Puskesmas dengan jumlah yaitu (3) bangunan. Dokumen sumber Perencanaan dan Pengadaan Aset berdasarkan Permendagri No 17 Tahun 2007 adalah sebagai berikut :

1) DKBMD sebagai dasar pelaksanaan pengadaan barang milik daerah.

2) DKPBMD sebagai dasar pelaksanaan pemeliharaan barang milik daerah.

Setelah melihat data pada tabel Perencanaan dan Pengadaan Barang di atas, dapat dilihat bahwa Perencanaan dan Pengadaan Aset pada Kabupaten Minahasa yang ditulis dalam formulir daftar rencana dan pengadaan barang sudah terselenggara dengan baik. Dinas Kesehatan yang merupakan salah satu SKPD yang membutuhkan biaya yang sangat besarsetiap tahunnya. Terlaksananya Perencanaan dan Pengadaan Aset Kabupaten Minahasa Utara melalui data dari Badan Pengelolaan Keuangan dan Barang Milik Daerah harus lebih tertib dan punya pengawasan yang lebih tinggi oleh tiap-tiap SKPD sebagai Pengguna aset dalam berbagai siklus pengelolaan yang diterapkan. Sehubungan dengan itu Pemerintah Kabupaten Minahasa Utara terus berusaha untuk menciptakan Good Governance dengan mengikuti berbagai Seminar, pelatihan, BIMTEK maupun studi banding ke daerah lainnya dengan harapan dapat memberikan manfaat kepada para aparatur daerah maupun secara umum kepada seluruh Pemerintah Kabupaten Minahasa Utara.

\section{Kesimpulan}

\section{KESIMPULAN DAN SARAN}

Dari hasil dan pembahasan di atas, maka dapat ditarik kesimpulan sebagai berikut :

a. Perencanaan Aset Pada Kabupaten Minahasa Utara sebagai pembantu pengelola dilakukan dengan berpedoman pada peraturan yang berlaku dan sudah sesuai dengan Permendagri No.17 Tahun 2007 tentang Pedoman Teknis Pengelolaan Barang Milik Daerah dan PP No.27 tahun 2014 tentang Pengelolaan Barang Milik Negara/Daerah.

b. Pengadaan Aset Pada Kabupaten Minahasa Utara sebagai pembantu pengelola dilakukan dengan berpedoman pada peraturan yang berlaku dan sudah sesuai dengan Permendagri No.17 Tahun 2007 tentang Pedoman Teknis Pengelolaan Barang Milik Daerah dan PP No.27 tahun 2014 tentang Pengelolaan Barang Milik Negara/Daerah.

c. Badan Pengelolaan Keuangan Dan Barang Milik Daerah Selaku Pembantu Pengelola masih kurang berkoordinasi dalam hal Perencanaan Dan Pengadaan Aset dengan Pihak SKPD lainnya.

\section{Saran}

BPKBMD Kabupaten Minahasa Utara selaku pembantu pengelola Aset/Barang Milik Daerah diharapkan melakukan koordinasi yang lebih baik lagi dengan semua SKPD selaku 
pengguna/pihak yang bertanggung jawab dalam pembuatan Perencanaan dan Pengadaan Aset sebagai bentuk kepatuhan terhadap peraturan yang berlaku dan mencantumkan spesifikasi barang dalam formulir rencana dan pengadaan barang unit agar lebih jelas diketahui oleh masyarakat. Juga dalam melakukan perencanaan diperlukan ketelitian agar tidak terjadi penambahan yang tidak terduga salah satunya harus diadakan survey yang lebil teliti sebelum melakukan perencanaan dan pengadaan barang milik daerah. Dengan demikian, Perencanaan dan Pengadaan Aset dapat dipertanggung jawabkan guna mewujudkan prinsip Good Governance.

\section{DAFTAR PUSTAKA}

Abeysekera I. 2003. Accounting For Intellectual Assets and Liabillities. JOURNAL OF HUMAN RESOURCE COSTING and ACOOUNTING. No.7.Vol.7 University Of Wollongong. Australia.

H Hong et al. 2008. Advisors And Asset Prices. JOURNAL OF FINANCIAL ECONOMICS. No.89. Vol. 268-287. University Priceton. USA. Tanggal akses 29 November 2015.

Hongren et al. 2013. Accounting.Pearson International Edition. Upper Saddle River. New Jersey.

Kolinug. 2015. Pengelolaan Aset Tetap Pada Dinas Pendapatan Pengelolaan Keuangan dan Aset Kota Tomohon. ISSN 2303-1104. Universitas Sam Ratulangi. Manado https://jurnalemba.7108.pdf.com. Tanggal akses 25 November 2015.

Mardiasmo dkk. 2008. Asset Management and Governance Analysing Vehicle Fleets In Asset Intensive Organisations. Page 1-20. Brisbane. Australia. Tanggal akses 28 November 2015.

Meulensteen J. 2010. Valuing Equity Using Accounting Numbers : The Role Of Intangible Assets. JOURNAL OF MASTER THESIS ACCOUNTING. Tilburg University. Tanggal akses 29 November 2015.

Michael dkk. 2014. Financial Reporting And Compliance Of Impairment Of Non-Current Assets In The Nigerian Bank. No.2. Vol.2 Jommo Kenyata University. Nairobi, Kenya. Tanggal akses 28 November 2015.

Nordiawan, D \& Hertinti, A.,2010, Akuntansi Sektor Publik, Edisi 2, Salemba Empat: Jakarta. Nordiawan, Putra dan Rahmawati.,(2012 : 7 ), Akuntansi Pemerintahan, Salemba Empat: Jakarta.

Nyemas et al. 2013. Pengelolaan Barang Milik daerah Pada Kabupaten Sintang. Jurnal Tesis PMIS PSIAN. Universitas Tanjungpura. Pontianak. https://jurnal.untan.ac.id>pdf1. Tanggal akses 25 November 2015.

Ouda H. 2014. A Practical Accounting Aproach For Heritage Assets Under Accrual Accounting. International Journal Of Governmental Financial Management. No.2 Vol.14. German University In Cairo. Tanggal akses 28 November 2015.

Pekei et al. 2014. The Effectiveness Of Local Asset Management. INTERNATIONAL JOURNAL OF BUSSINESS and MANAGEMENT. Vol 3. Brawijaya University. Malang. Tanggal akses 29 November 2015.

Peraturan Daerah Kabupaten Minahasa Utara Nomor 12 Tahun 2014, Tentang Uraian Tugas Dan Fungsi Badan Pengelolaan Keuangan Dan Barang Milik Daerah Kabupaten Minahasa Utara.

Peraturan Menteri Dalam Negeri Nomor 17 Tahun 2007, Tentang Pedoman Teknis Pengelolaan Barang Milik Daerah.

Peraturan Menteri Dalam Negeri Nomor 52 Tahun 2015, Tentang Penyusunan Anggaran Pendapatan Dan Belanja Daerah (APBD) .

Peraturan Pemerintah Nomor 27 Tahun 2014, Tentang Pengelolaan Barang Milik Daerah. 
Peraturan Presiden Nomor 54 Tahun 2010. Tentang Pengadaan Barang/Jasa Pemerintah. Sanusi,Anwar., 2011, Metodologi Penelitian Bisnis. Salemba Empat: Jakarta.

Siregar. 2007. Pengaruh Pengelolaan Barang Milik Daerah Terhadap Pengamanan Aset Daerah. Universitas Negeri Medan. https://digilib.unimed.ac.id. Tanggal akses 25 November 2015.

Sugiyono., 2010a, Metode Penelitian Kuantitatif, Kualitatif Dan R\&D. Alfabeta:Bandung. Undang-Undang Nomor 25 Tahun 2005, Tentang Perencanaan Nasional Dan Peraturan Pelaksanaannya.

Yusuf, M., 2011, 8 Langkah Pengelolaan Aset Daerah Menuju Pengelolaan Keuangan Daerah Tebaik, Cetakan Kedua, Salemba Empat: Jakarta. 